\title{
Prospective trial comparing contrast swallow, computed tomography and endoscopy to identify anastomotic leak following oesophagogastric surgery
}

Brian A. Hogan · Desmond C. Winter •

David Broe · Patrick Broe · Michael J. Lee

Published online: 20 August 2008

(C) Springer Science+Business Media, LLC 2008

Erratum to: Surg Endosc (2008) 22(3):767-771

DOI 10.1007/s00464-007-9629-6

The full name of the second author is Desmond C. Winter.

This article appeared in Vol. 22, Number 3, page 767.

The online version of the original article can be found under doi:10.1007/s00464-007-9629-6.

B. A. Hogan $(\bowtie) \cdot$ M. J. Lee

Department of Radiology, R.C.S.I. Educational \& Research

Centre, Beaumont Hospital, Dublin 9, Ireland

e-mail: bhogie@eircom.net

Present Address:

B. A. Hogan

31, 1535 Trossacks Avenue, London, ON, Canada N5F 4R1

D. C. Winter - D. Broe - P. Broe

Department of Surgery, Beaumont Hospital, Dublin, Ireland 